\title{
IDENTIFICATION OF ORNAMENT AND FAUNA POTENTIAL OF SIBIUK CAVE IN CIAMPEA BOGOR SUBDISTRICT
}

\author{
RATNA SARI HASIBUAN ${ }^{*}$, Ken DARA CitA, AND FATHUl ILMI \\ Forestry Study Program, University of Nusa Bangsa Bogor, Tanah Sereal, Bogor, 16166, Indonesia \\ *Email: ratnasylva@gmail.com
}

Accepted June 8, 2020 / Approved October 2, 2020

\begin{abstract}
The beauty of ornament and uniqueness of cave is the potential of Sibiuk Cave that could be made into special interest tourism. Sibiuk Cave is known as Air Conditioner Cave for it has three doors that make the cave cold inside. This study aims to identify the potential that Sibiuk Cave has, which located in Ciampea Subdistrict. This study was conducted from February to May 2020 by applying survey forward method and top to bottom survey system in making Sibiuk Cave profile map and direct collection with rapid assessment method to identify cave ornament and fauna. The results of the study were the existence of stalactites, stalagmite, chamber, column, and boulder as well as faunas such as ancient shrimp (Stenasellus sp), cave cricket (Rhaphidophora sp), tailless whip scorpion (Stygophrynus dammermani), whip scorpion (Thelyphonus caudatus), millipede (Orthomorpha coarctata), land snail (Leptopoma celebesianum), centipede (Scutigeria sp), bat (Rousettus amplexicaudatus), and swift (Collocalia vestita). SIbiuk cave potential is expected to be expanded into special interest tourism of rock climbing, caving, speleology and biospeleology.
\end{abstract}

Key words: cave fauna, sibiuk cave, cave ornament, forward survey

\section{INTRODUCTION}

Cave is an example of endokarst morphology. Cave is a natural formation in the form of karst space formed in the underground limestone area, both of which might stand alone or connected to other rooms as the result of water dissolution process and geology activity of an area (Ford and Williams 1989; Aidin 2017; Uca and Angriani 2018). These caves are the remnants after parts of the eroded limestone gone with the water. The remnants of the eroded limestone are in the form of cavities. The cavities are combined into an enormous hole and is called cave. Cave is an environment with unique and specific characteristics. One of cave main features is a pitch black condition with no sunlight (ASC 2019). The outer side of a cave still receives the sunlight, and the environmental change outside the cave still highly influences its environment. Based on the range of sunlight, the cave environment is separated into three zones: bright zone, transition zone (dim), and dark zone (eternal) (ASC 2019).

Based on the formation process, a cave is divided into three (Mylroie and Carew 2003):

1. Pit caves, characterized with the mouth of the cave descending from land surface with steep slope;

2. Phreatic caves, characterized with wide horizontal mouth, formed due to limestone dissolution by ground water flow;

3. Fracture caves, are caves formed due to expanding crack on limestone bedding.

Cave has economic benefits, one of which is cave potential as special interest tourism, fauna habitat, water source, and carbon dioxide absorber (Mijiarto et al.
2014). Rahmadi (2007) says that cave has much potential so it needs to be protected, and conservation efforts must be made. Cave needs to be protected and conserved because:

1. It is easily damaged due to environmental change;

2. It has unique biodiversity inside;

3. Cave fauna becomes extinct easily because of the small population and significantly low tolerance for environmental change;

4. It is a natural laboratory to learn biology, living creature evolution and history of past climate;

5. Home for faunas that are pivotal to ecological balance (bat) and fauna with high economic value (swift);

6. It contains vital historical heritage;

7. It acts as a crucial economic source, especially as underground water reservoir;

8. It acts as a tourism object with high economic value if managed properly.

Based on the passage, caves can be divided into two parts, i.e., horizontal and vertical. Caves with relatively flat passage is called horizontal cave. Some horizontal caves come with relatively short passages that resemble pits. Others come with lengthy and winding passages, resembling a labyrinth. Vertical caves are also called luweng, formed from the process of collapse doline, solution doline, and vertical cave system. The bottom of the basin in vertical caves is used as the surface runoff entrance into the underground river system. (Firdauzy and Zuharnen, 2020).

Ciampea Subdistrict owns several vertical caves, one of which is Sibiuk Cave. Sibiuk cave has three mouths which make the inside cold as if Air Conditioner 
exists. It also has a passage that extends downward. The tracing conducted in vertical caves used Single Rope Technique (SRT) tool. The tracing conducted in vertical caves used Single Rope Technique (SRT) tool. SRT is a set of tools used for the importance of going up and down during outdoor activities using only a single rope supported with other devices (ASC 2019).

Sibiuk Cave potential remains unidentified until today because it is considered a vertical cave that is difficult to explore. This study aims to identify the potential of Sibiuk Cave in Ciampea Subdistrict, especially its ornament and faunas. This study is essential under the cave conservation efforts in which the location is included in Geopark area as inaugurated in 2018. Additionally, the area development is expected to be directed into a special interest tourism area.

\section{RESEARCH METHOD}

The study was conducted in Sibiuk Cave, Cibadak Village, Ciampea Subdistrict, Bogor Regency, West Java Province (Figure 1). Sibiuk cave is located at coordinate of $06^{\circ} 33^{\prime} 09.08^{\prime \prime} \mathrm{SL}-106^{\circ} 41^{\prime} 14.54$ " EL. The data recorded in this study consisted of three categories which were general condition data of research location, Sibiuk cave profile, and cave characteristics. The data collection tools and materials are represented in Table 1.

This study applied descriptive method. The descriptive research method means describing the data collected from the field survey concerning Sibiuk cave. The survey results covered observation, measurement, and data recording in the field. The process of cave's profile data collection was carried out by determining survey points. The survey points were then known as station. The survey used was forward survey, while the survey system applied in collecting the data was Top to Bottom. The findings inside the cave, such as cave ornament, faunas, etc., were recorded with rapid assessment (Bismark 2011). It was done by entering the cave's mouth and made station points, observed the phenomena on each point, including the cave ornament and faunas (if the fauna's name was undefined, it was then identified in University of Nusa Bangsa's laboratory) until the station was impassable. The humidity was measured with a hygrometer tool by placing it inside the cave to determine the humidity and temperature. The acidic water level in the cave was identified by placing litmus paper on puddles. Red litmus paper that turned into blue showed that the water sample was alkaline. All data collected from the field were recorded and identified.

\section{a. Forward survey method}

Forward survey method is a method applied by users with tool reading technique and the recorder is located in station 1 (first), while the pointer (target) in station 2 (second). After the tool reading was carried out, the pointer moved forward to the set next station, and the tool reader moved forward exactly to the pointer without changing the station point of the previous pointer, and so on (Figure 2).

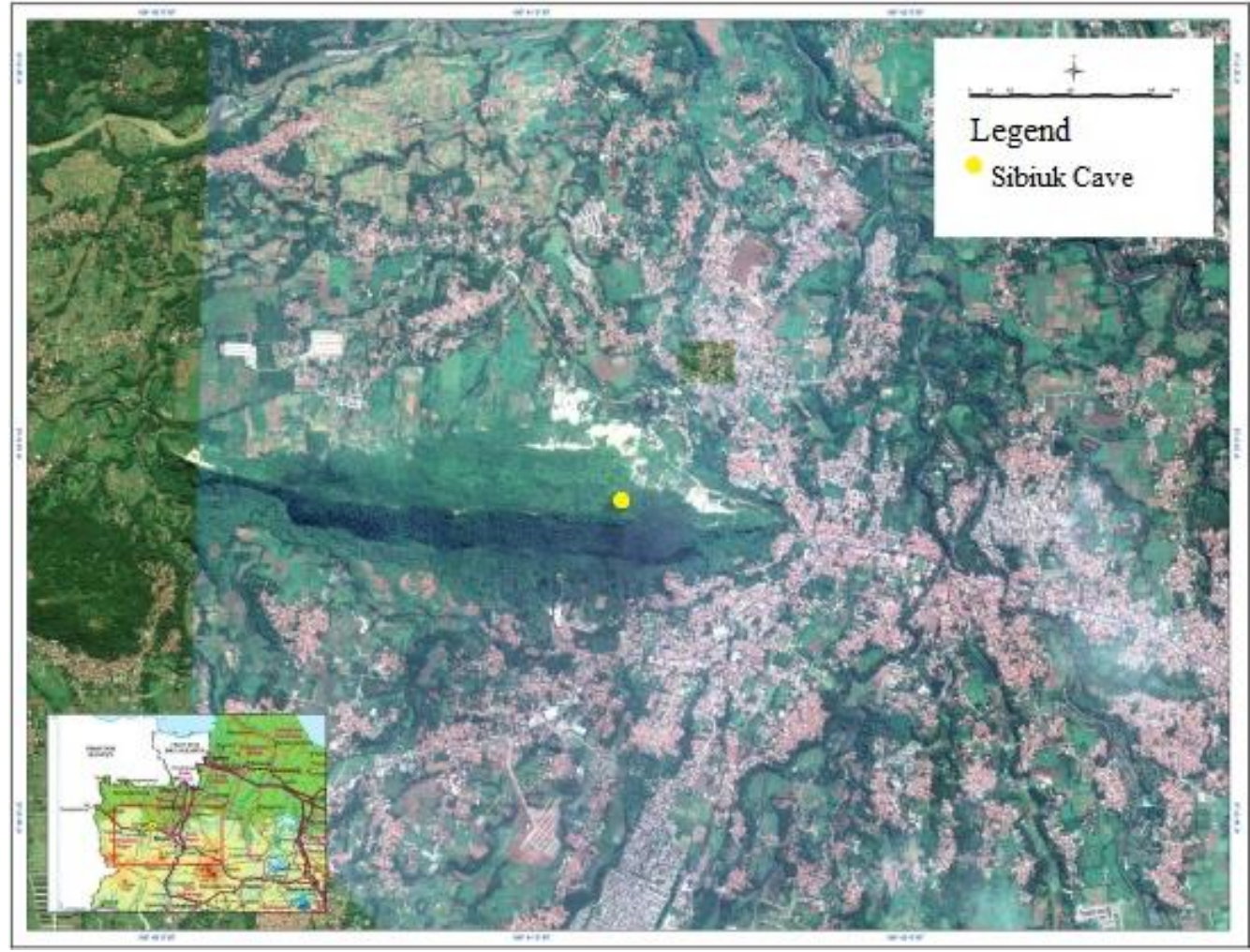

Figure 1. Map of Sibiuk Cave research location 
Table 1 Research tools and materials

\begin{tabular}{cll}
\hline No. & \multicolumn{1}{c}{ Tool } & \multicolumn{1}{c}{ Function } \\
\hline 1 & Stationery & Write the required data results \\
2 & Camera & Documenting all objects and activities that could support the research \\
3 & Roll meter & To measure the length, width, and direction of the cave passage. \\
4 & Laptop & To process the data and make report \\
5 & Compass & To measure azimuth or horizontal angles \\
6 & Worksheet & To write the collected data \\
7 & Tracing paper & A media to sketch the collected data \\
8 & Clinometer & A tool to measure vertical or inclination angles \\
9 & Cellphone & A supporting device \\
10 & GPS & To find cave coordinate \\
11 & SRT set & Complete equipment to go down the vertical cave \\
12 & Hygrometer & To measure the temperature and humidity of a place \\
13 & Litmus paper & To measure the pH of the water \\
14 & Tweezers & To take fauna sample \\
15 & Net & A supporting tool to take faunas in water or cave roof \\
16 & Brush & To take small and vulnerable faunas \\
17 & Plastic specimen & A container to keep faunas \\
\hline
\end{tabular}

Table 2. Types of data and method used.

\begin{tabular}{|c|c|c|c|c|}
\hline No & Parameter & Variable & Source & Method \\
\hline 1 & $\begin{array}{l}\text { General } \\
\text { condition of } \\
\text { research } \\
\text { location }\end{array}$ & $\begin{array}{l}\text { Location and area, history and } \\
\text { status, climate and rain fall, } \\
\text { topography and height, cave } \\
\text { distribution }\end{array}$ & $\begin{array}{l}\text { a. Management } \\
\text { office } \\
\text { b. Secondary } \\
\text { data }\end{array}$ & $\begin{array}{l}\text { a. Interview } \\
\text { b. Literature review }\end{array}$ \\
\hline 2 & $\begin{array}{l}\text { Sibiuk Cave } \\
\text { Profile }\end{array}$ & $\begin{array}{l}\text { Length, width, passage height, } \\
\text { types and location of cave } \\
\text { ornament, passage cross section } \\
\text { and cave mouth shape, water } \\
\text { presence }\end{array}$ & $\begin{array}{l}\text { Field } \\
\text { observation }\end{array}$ & $\begin{array}{l}\text { Cave mapping with forward survey } \\
\text { method, while the survey system } \\
\text { applied in collecting the data is Top to } \\
\text { Bottom. }\end{array}$ \\
\hline 3 & $\begin{array}{l}\text { Sibiuk Cave } \\
\text { Characteristics }\end{array}$ & $\begin{array}{l}\text { Type, substrate, and zone of cave } \\
\text { where fauna is found }\end{array}$ & $\begin{array}{l}\text { Field } \\
\text { observation }\end{array}$ & $\begin{array}{l}\text { Direct collection with rapid } \\
\text { assessment method (Bismark 2011) }\end{array}$ \\
\hline
\end{tabular}

Figure 2 Survey forward technique method Source: ASC (2019)

b. Top to Bottom Survey System

Top to Bottom Survey System Method is a measurement and data collection that start from cave mouth and end up at the end of cave passage.

The data to be collected among others:

- Writing and measuring the information of cave profile, such as geographical location of cave mouth;

- Determining the mapping station, which was a point in the cave passage of the survey location. The next mapping station was determined according to the principal condition in the cave, which represented the passage width change, roof height change, passage direction change, floor inclination change, as well as it was at the tie point of passage branching;

- Measuring at each station, i.e., distance between stations, width, station inclination height, types of water dripping;

- Writing the findings in cave like ornament, cave fauna, and other things by applying rapid assessment (Bismark 2011) method.

The data collected from field survey were than analyzed by using formulas referring to ASC (2019). 
After the data management was analyzed and data on variable were obtained, the numbers were used as mapping reference. After the required variable data were obtained, the data were then processed by inputting data into software, which was Compass Project Manager app (ISS 2014a).

\section{RESULT AND DISCUSSION}

\section{General condition of research location}

The area of Ciampea Subdistrict is 3.297,91 hectares with an altitude of 354 MASL. (BPS 2017). The total population is 159.259 people that consists of 81.809 males and 77.450 females. The administrative boundary of Ciampea subdistrict is: Rancabungur subdistrict on North side, Cibungbulang subdsitrict on West side, Tenjolaya and Pamijahan subdistricts on South side, and Dramaga subdistrict on East side.

The climatic condition in the research location is considered as an area with tropical wet climate characteristics. The research location has A1 climate type, which means no dry season. The average temperature in the research location was $26^{\circ} \mathrm{C}$ and the average humidity was $>80 \%$, the wind speed was around $52 \mathrm{~km} /$ day (Novian, 2010). The soil condition is divided into three types, i.e., rendzina, grayish brown alluvial, and red latosol. According to Atmosentono (1968), this area is included into rendzina complex and lithosol type with andesite limestone as the main material. Lithosol is solid rock with a paper-thin layer of soil on top, while rendzina has rather shallow to shallow. This soil reacts neutrally and varied in certain depths. The organic and nitrogen content on the top are high, with average $\mathrm{P}_{2} \mathrm{O}_{5}$ and low $\mathrm{K}_{2} \mathrm{O}$, while the $\mathrm{CaO}$ level in the entire soil layer is high in which the deeper it gets, the higher the level is. The physical property of this soil is sensitive toward erosion and landslide hazard, which makes drainage canals and tillage much needed to repair the soil structure. Latosol soil is granular in nature, it stimulates excellent deep drainage.

\section{Sibiuk Cave Profile}

Sibiuk cave has three doors, which are upper, middle, and lower doors. Each door has different depth. The upper door has around 15 meters deep, the middle door is around 40 meters, and the lower door is less than 50 meters. This research conducted the tracing from the middle door with around 40 meters deep.

The cave mapping is made to document the cave (Uca and Angriani 2018). Map can be a useful tool to take certain decisions regarding the mapped objects under the direction of special interest tourism management by rock climbing and caving. According to Ko (2001), one of the requirements to develop cave as the direction of special interest tourism is a map. Firdauzy and Zuharnen (2020) add that cave map is one of cartography final product and is part of geographic information. Sibiuk cave profile map can be seen in Figure 3.

The research results showed as much as ten stations were found, starting from the cave mouth (bright zone) to eternal dark zone. Menurut Rahmadi C (2007) believe that cave environment is commonly divided into four zones, which are cave entrance, transition zone (dim zone), dark zone, and eternal dark zone.

Sibiuk is a vertical cave with pit cave mouth. Mylroie et al. 2003 state that pit cave is formed with several characteristics, such as cave mouth descending from land surface with steep slope, so the cave management can be directed as rock climbing special interest tourism in the future. Ko (2001) and Laksmana (2016); as well as ASC (2019) say that special interest tourism, especially caving, need SRT help.

The total length of Sibiuk cave covering all stations and substations was 117.63 meters; the roof of the cave mouth was 4.10 meters high and 3.27 meters wide. The longest station as noted from the research results was station five to station six by 13.12 meters. The second longest was station three to station four by 12.3 meters. The significant cave floor inclination change was in station four to five, with a slope of $-90^{\circ}$ (perpendicular), and in station six to seven, with a slope of $-31^{\circ}$ entering the pin-hole that was directed to the second passage. The cave floor inclination change with a negative sign (-) showed that the floor was descending. On the opposite, the floor was ascending if it did not come in a negative sign (-) (Table 3). Cave morphometry could be acquired from observation and data processing results. Sibiuk cave had one chamber and two passages that connect each chamber. Cave mouth and dim zone (stations one and two) had no cave fauna, but a few twigs fallen from the surrounding trees that went into the cave passage were found. This zone looked dry, no seepage or water droplet. This zone was affected by sunlight that entered the mouth of the cave. Table 3 shows the type of water dripping, some seeped into the cave wall and some dripped. This phenomenon proved that the interior of Sibiuk cave was humid. The humidity ranged around 8182 , and puddles were found in several stations.

\section{Sibiuk Cave Characteristics}

Caves are where the adaptation and evolution process of various organisms take place. The formed caves are habitat to living creatures. Dark caves with limited organic source create a unique and interesting habitat to study (Setyaningsih 2011). The karst formation process might occur due to the dissolution of limestone caused by rain. This condition lasts continuously which in geology term is called karstification. Sibiuk cave is a karst cave (limestone) with 40 meters chamber that consists of giant ornaments. Knowledge about cave ornament is expected to bring the cave management into speleology special interest tourism. 


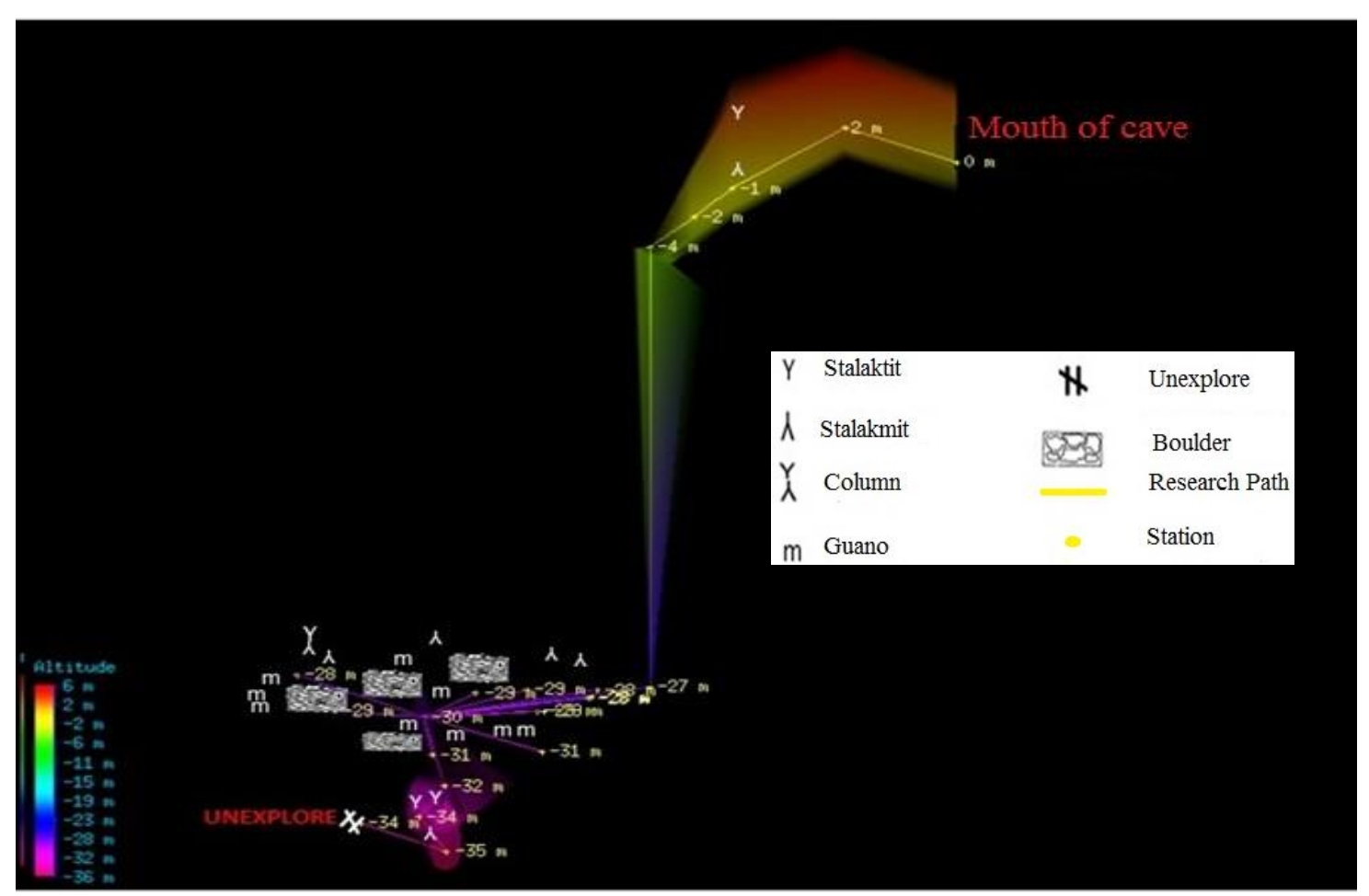

Figure 3 Sibiuk cave's profile map and ornament distribution with Compass Project Manager app

Table 3. Physical condition of Sibiuk cave passage

\begin{tabular}{|c|c|c|c|c|c|c|c|c|}
\hline \multirow{2}{*}{$\begin{array}{l}\text { Chamber/ } \\
\text { passage }\end{array}$} & \multirow[b]{2}{*}{ Station } & \multirow{2}{*}{$\begin{array}{c}\text { Flat } \\
\text { distance } \\
(\mathrm{m})\end{array}$} & \multicolumn{2}{|c|}{ Average } & \multirow{2}{*}{$\begin{array}{c}\text { Inclination } \\
\left(^{\circ}\right)\end{array}$} & \multirow{2}{*}{$\begin{array}{l}\text { Measurement } \\
\text { method }\end{array}$} & \multirow{2}{*}{$\begin{array}{l}\text { Ornament/ } \\
\text { zone }\end{array}$} & \multirow{2}{*}{$\begin{array}{l}\text { Type of } \\
\text { water } \\
\text { dripping }\end{array}$} \\
\hline & & & Width & Height & & & & \\
\hline Passage 1 & $\begin{array}{c}\text { St } 0-\mathrm{St} \\
01\end{array}$ & 4.80 & 2.90 & 4.10 & 23 & B & $\begin{array}{l}\text { Twig/ } \\
\text { bright }\end{array}$ & - \\
\hline Passage 1 & $\begin{array}{l}\text { St } 01- \\
\text { St } 02\end{array}$ & 5.51 & 1.09 & 4.42 & -32 & B & $\begin{array}{l}\text { Twig/ } \\
\text { Dim }\end{array}$ & - \\
\hline Passage 1 & $\begin{array}{l}\text { St } 02- \\
\text { St } 03\end{array}$ & 2.14 & 1.10 & 5.80 & -42 & B & $\begin{array}{c}\text { Stalagmite, cave } \\
\text { fauna/ } \\
\text { Dim }\end{array}$ & Droplet \\
\hline Passage 1 & $\begin{array}{l}\text { St } 03- \\
\text { St } 04\end{array}$ & 2.42 & 1.50 & 3.11 & -40 & B & $\begin{array}{c}\text { Stalagmite, cave } \\
\text { fauna/ } \\
\text { Dim }\end{array}$ & Droplet \\
\hline Passage 1 & $\begin{array}{l}\text { St } 04- \\
\text { St } 05\end{array}$ & 21.0 & 2.14 & 4.10 & -90 & B & -/Dark & Seepage \\
\hline Passage 1 & $\begin{array}{l}\text { St } 05- \\
\text { St } 06\end{array}$ & 11.76 & 12.56 & 27.00 & -12 & B & $\begin{array}{l}\text { Guano/ } \\
\text { Dark }\end{array}$ & - \\
\hline Chamber & St 06 - a & 8.35 & - & - & 11 & B & $\begin{array}{c}\text { Guano, Cave } \\
\text { Fauna/ } \\
\text { Dark }\end{array}$ & Droplet \\
\hline Chamber & St $06-b$ & 5.73 & - & - & 6 & B & Guano/Dark & - \\
\hline Chamber & St $06-c$ & 5.00 & - & - & 4 & B & Guano/Dark & - \\
\hline Chamber & St $06-d$ & 7.81 & - & - & 11 & $\mathrm{~B}$ & $\begin{array}{c}\text { Cave Fauna/ } \\
\text { Dark }\end{array}$ & Droplet \\
\hline Chamber & St $06-\mathrm{e}$ & 7.10 & - & - & 7 & B & $\begin{array}{c}\text { Guano, Cave } \\
\text { Fauna/ } \\
\text { Dark }\end{array}$ & - \\
\hline Chamber & St $06-\mathrm{f}$ & 5.32 & - & - & 8 & B & Guano Cave & - \\
\hline
\end{tabular}




\begin{tabular}{|c|c|c|c|c|c|c|c|c|}
\hline \multirow{2}{*}{$\begin{array}{l}\text { Chamber/ } \\
\text { passage }\end{array}$} & \multirow[b]{2}{*}{ Station } & \multirow{2}{*}{$\begin{array}{l}\text { Flat } \\
\text { distance } \\
(\mathrm{m})\end{array}$} & \multicolumn{2}{|c|}{ Average } & \multirow{2}{*}{$\begin{array}{c}\text { Inclination } \\
\left({ }^{\circ}\right)\end{array}$} & \multirow{2}{*}{$\begin{array}{l}\text { Measurement } \\
\text { method }\end{array}$} & \multirow{2}{*}{$\begin{array}{l}\text { Ornament/ } \\
\text { zone }\end{array}$} & \multirow{2}{*}{$\begin{array}{c}\text { Type of } \\
\text { water } \\
\text { dripping }\end{array}$} \\
\hline & & & Width & Height & & & & \\
\hline & & & & & & & $\begin{array}{l}\text { Fauna/ } \\
\text { Dark }\end{array}$ & \\
\hline Chamber & St $06-\mathrm{g}$ & 7.74 & - & - & 14 & B & $\begin{array}{c}\text { Cave Fauna/ } \\
\text { Dark }\end{array}$ & Droplet \\
\hline Chamber & St $06-\mathrm{h}$ & 5.43 & - & - & 10 & B & $\begin{array}{c}\text { Cave Fauna/ } \\
\text { Dark }\end{array}$ & Seepage \\
\hline Chamber & St $06-\mathrm{i}$ & 5.81 & - & - & -12 & B & $\begin{array}{c}\text { Cave Fauna/ } \\
\text { Dark }\end{array}$ & Seepage \\
\hline Chamber & St $06-\mathrm{j}$ & 7.70 & - & - & -8 & B & Guano/Dark & - \\
\hline Chamber & St $06-\mathrm{k}$ & 9.76 & - & - & 11 & B & Guano/Dark & - \\
\hline Passage 2 & $\begin{array}{c}\text { St } 06- \\
\text { St } 07\end{array}$ & 6.50 & 0.70 & 0.70 & -26 & B & Cave fauna/Dark & Seepage \\
\hline Passage 2 & $\begin{array}{l}\text { St } 07- \\
\text { St } 08\end{array}$ & 2.28 & 3.50 & 0.35 & -35 & $\mathrm{~J}$ & Cave fauna/Dark & Droplet \\
\hline Passage 2 & $\begin{array}{l}\text { St } 08- \\
\text { St } 09\end{array}$ & 2.62 & 2.70 & 2.27 & -33 & $\mathrm{~J}$ & $\begin{array}{c}\text { Cave } \\
\text { fauna/Eternal } \\
\text { dark }\end{array}$ & Droplet \\
\hline Passage 2 & $\begin{array}{l}\text { St } 09- \\
\text { St } 10\end{array}$ & 3.86 & 1.80 & 2.60 & 25 & $\mathrm{~J}$ & $\begin{array}{c}\text { Cave } \\
\text { fauna/Eternal } \\
\text { dark }\end{array}$ & Seepage \\
\hline
\end{tabular}

Information: B: Stand, J: Squat.

Setyaningsih (2011) say that what found in dark and eternal dark zones are animals like grasshopper, centipede, spider, and millipede on the cave floor and wall. The same things were also found in Sibiuk cave, in which pink ancient shrimp (Stenasellus $s p$ ) found in puddles in cave floor was included into Isopods type (ISS 2014b). The research conducted by Rahmadi and Suhardjono (2004) shows that this animal is newly- discovered and can enrich cave fauna diversity. The animals found in Sibiuk cave besides ancient shrimp were cave cricket (Rhaphidophora $s p$ ), tailless whip scorpion (Stygophrynus dammermani), whip scorpion (Thelyphonus caudatus), millipede (Orthomorpha coarctata), land snail (Leptopoma celebesianum), centipede (Scutigeria sp), bat (Rousettus amplexicaudatus) and swift (Collocalia vestita).

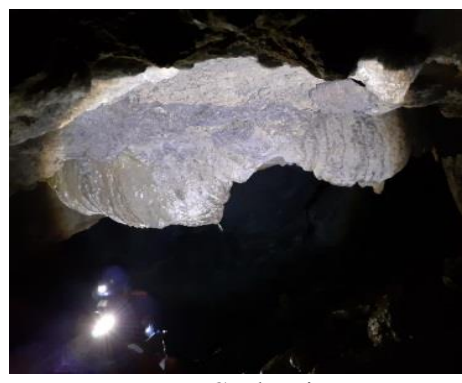

a. Stalactite

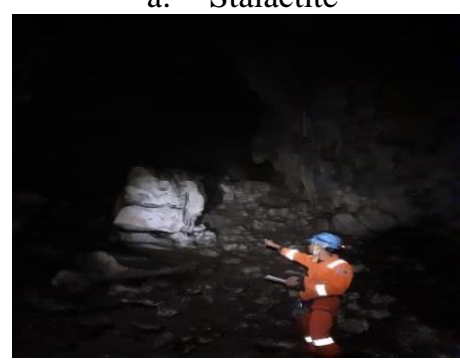

d. boulder

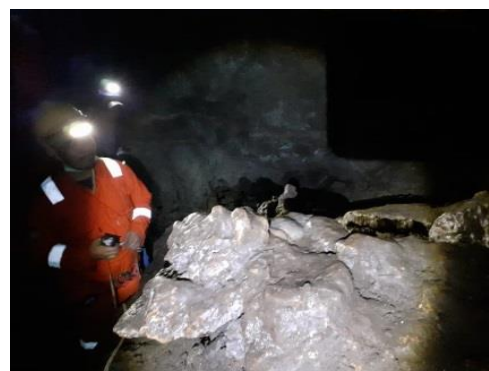

b. Stalagmite

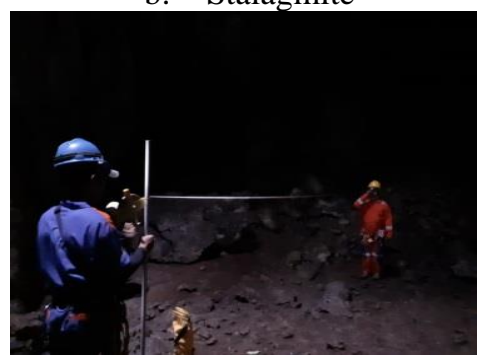

e. Chamber

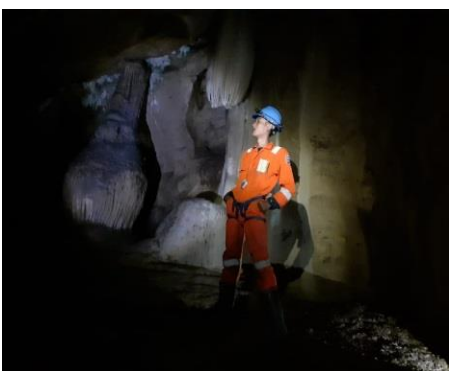

c. Column

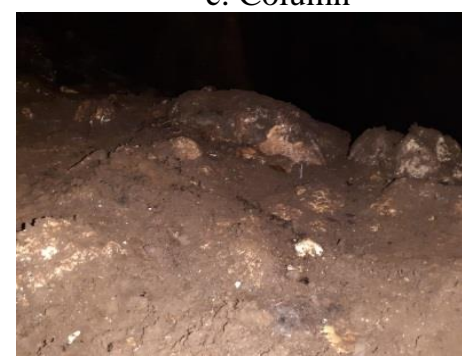

f. Guano

Figure 4. Sibiuk Cave Ornament 


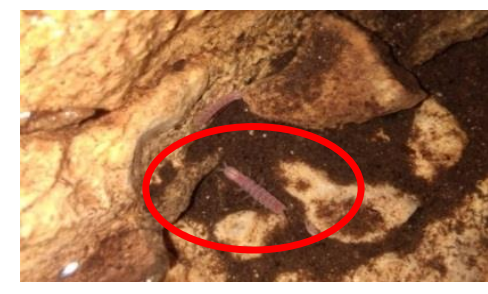

Ancient shrimp (Stenasellus sp)

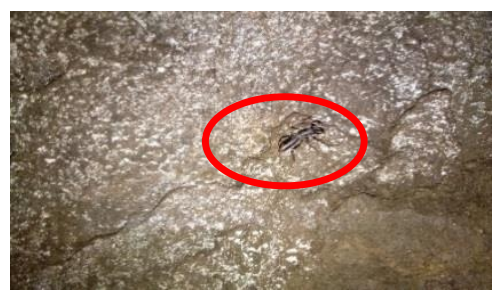

Whip scorpion (Thelyphonus caudatus)

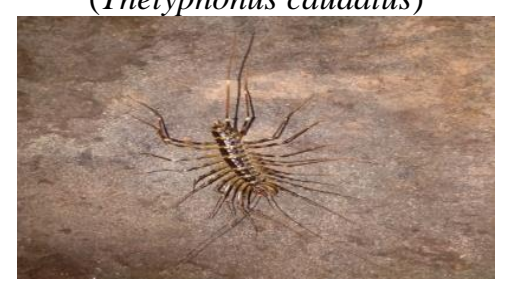

Centipede (Scutigeria $s p$ )

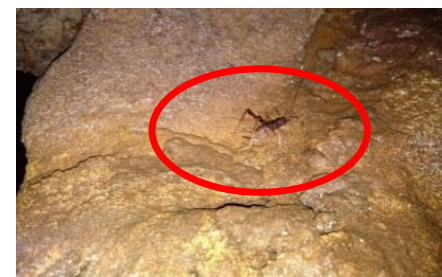

Cave cricket (Rhaphidophora sp)

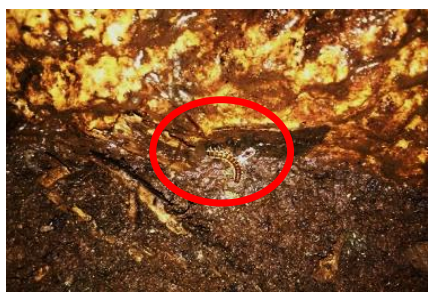

Millipede

(Orthomorpha coarctata)

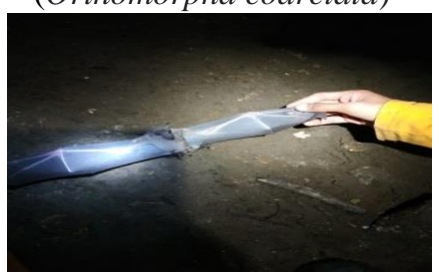

Bat

(Rousettus amplexicaudatus)

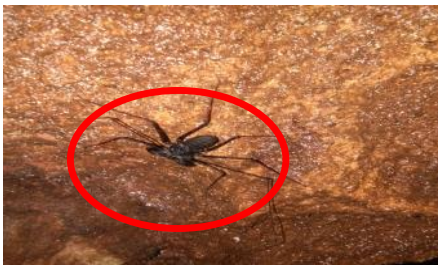

Tailless whip scorpion

(Stygophrynus dammermani)

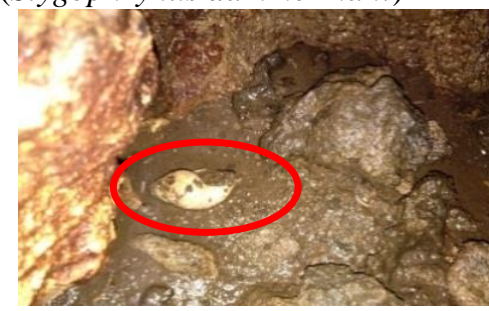

Land snail

(Leptopoma celebesianum)

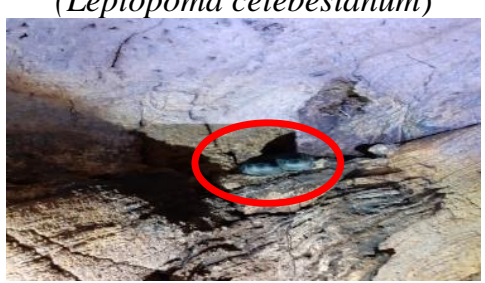

Swift

(Collocalia vestita)

Figure 5. Sibiuk Cave Fauna

Endokarst faunas must adapt themselves to the environmental conditions to survive. The characteristics of endokarst habitat are evaluated from temperature, humidity, and water $\mathrm{pH}$. The Sibiuk cave's temperature is around $22^{\circ}-23^{\circ}$ Celcius, with humidity level around $81 \%$ $82 \%$ and water $\mathrm{pH}$ level at 8 . Cave fauna with unique shape like ancient shrimp (Stenasellus $s p$ ) is pink colored shrimp that lives in salt water. According to a study conducted by Rahmadi and Suhardjono (2004), Stenasellus is one of the crustacean members from Isopods and included into primitive group; some of its ancient live up to today in salt water. Stenasellus lives in water with high-level of salinity, but this fauna has gone through a long evolution process. It is found in fresh water in some caves in Bogor, including Sibiuk cave, which can be directed to biospeleology special interest tourism. ASC (2019) states that biospeleology is the branch of speleology science that learns the cave ecosystem's existence; later tourists will go on tour and increase their knowledge, especially about cave faunas.

Cave ecosystem is an unfamiliar ecosystem with dark, humid, and unreachable environment. Many caves are compromised and neglected, especially vertical caves because it requires substantial cost to do research or observation. In addition, since physical strength and skills in climbing or descending vertical caves are crucial, it is important to have a trained instructor or interpreter who at least owns a level-1 certificate according to the Ministry of Manpower (kemnaker).

\section{CONCLUSION}

The potentials of Sibiuk cave were the cave ornaments, such as stalactites, stalagmite, chamber, and column. Moreover another potential in terms of cave faunas were ancient shrimp (Stenasellus $s p$ ), cave cricket (Rhaphidophora sp), tailless whip scorpion (Stygophrynus dammermani), whip scorpion (Thelyphonus caudatus), millipede (Orthomorpha coarctata), land snail (Leptopoma celebesianum), centipede (Scutigeria sp), bat (Rousettus amplexicaudatus), and swift (Collocalia vestita). The potentials of Sibiuk cave and its development are expected to be directed into special interest tourism of rock climbing, caving, speleology, and biospeleology. 


\section{REFERENCES}

[ASC] Acintyaçûnyâta Speleological Club. 2019. Diktat Speleologi. Matoreang E, Yenawati (ed.). Yogyakarta: ASC.

Aidin A. 2017. Identifikasi dan arahan pemanfaatan kawasan eko karst di Kecamatan Balocci Kabupaten Pangkep [skripsi]. Makasar: UIN Alaudin Makasar.

Atmosentono H. 1968. Tanah Sekitar Bogor. Bogor: Lembaga Penelitian Tanah.

BPS. 2017. Kecamatan Ciampea Dalam Angka 2017. Bogor: BPS Kab. Bogor.

Bismark M. 2011. Prosedur Operasi Standar (SOP) untuk Survei pada Kawasan Konservasi. Bogor: Pusat Penelitian dan Pengembangan Perubahan Iklim dan Kebijakan Badan Penelitian dan Pengembangan Kehutanan, Kementerian Kehutanan, Indonesia Kerjasama Dengan: International Tropical Timber Organization (ITTO).

Firdauzy AA, Zuharnen. 2020. Aplikasi kartografi dalam survei dan teknik pemetaan gua horizontal. Studi kasus: Gua Nguwik Di Desa Donorejo Kecamatan Kaligesing Kabupaten Purworejo. Jurnal. Bumi Indonesia. 9(1).

Ford DC, Williams PW. 1989. Karst Geomorphology and Hydrology. London: Chapman and Hall.

[ISS] Indonesia Speological Society. (2014a). Panduan Compass. Indonesia Speological Society. https://caves.or.id/arsip/1359

[ISS] Indonesia Speological Society. (2014b). Stenasellus Project "Mainstreaming cave biodiversity for all stakeholders." Indonesia Speological Society. https://caves.or.id/stenasellus-project
KO RKT. 2001. Objek Wisata Alam. Bogor: Yayasan Buena Vista.

Laksmana EE. 2016. Stasiun Nol Teknik Teknik Pemetaan Dan Survey Hidrologi Gua. Yogyakarta: ASC.

Mijiarto J, Basuni S, Sunarminto T. 2014. Nilai ekonomi jasa lingkungan Kawasan Karst Gua Gudawang. Media Konservasi. 19(3): $154-160$.

Mylroie JE, Carew JL. 2003. Karst development on carbonate islands, Speleogenes. Evol. Karst Aquifers. 1(2): $1-21$.

Novian. 2010. Perencanaan Lansekap Gunung Kapur Cibadak Ciampea Bogor sebagai kawasan wisata terpadu [skripsi]. Bogor: Institut Pertanian Bogor.

Rahmadi C. 2007. Ekosistem karst dan gua: Gudangnya keanekaragaman hayati yang unik [makalah]. Disampaikan pada Pelatihan Kader Lingkungan Diselenggarakan Oleh Kapedal Gunung Kidul, Wonosari, 21 November 2007.

Rahmadi C, Suhardjono YR. 2004. Gua-gua Tumbang Topus, Hulu Sungai Barito, Kalimantan Tengah. Bogor: Pusat Penelitian Biologi LIPI.

Satrio, Sidauruk P, Pratikno B. 2012. studi iklim dan vegetasi menggunakan pengukuran isotop alam stalaktit Goa Seropan, Gunung Kidul-Yogyakarta. Jurnal Ilmiah Aplikasi Isotop dan Radiasi. 8(1): 4352.

Setyaningsih M. 2011. Keanekaragaman fauna gua karst di Pangandaran Jawa Barat. Proseding Penelitian Bidang Ilmu Eksakta. 35-44.

Uca, Angriani R. 2018. Pemetaan Gua Kalibbong Aloa Kawasan Karst Pangkep. Jurnal Sainsmat. 7(2): 92101. 